\title{
Professional Learning Community (PLC): Approach to Enhance Students' Achievement in Language Learning at Public University, Malaysia
}

\author{
Shamsudin Othman ${ }^{1, *}$, Abdul Rasid Jamian ${ }^{2}$, Azhar Md. Sabil ${ }^{1}$, RozitaRadhiah Said ${ }^{1}$, \\ Rosmaria Omar ${ }^{1}$

\begin{abstract}
${ }^{1}$ Language and Humanities Education, Faculty of Educational Studies, University Putra Malaysia, 43400, Serdang, Selangor, Malaysia
${ }^{2}$ Department of Malay Language Literature, Faculty of Language and Communication, Sultan Idris University of Education, 35900 Tanjong Malim, Perak, Malaysia
\end{abstract}

Received October 27, 2019; Revised December 2, 2019; Accepted December 24, 2019

Copyright $\odot 2020$ by authors, all rights reserved. Authors agree that this article remains permanently open access under the terms of the Creative Commons Attribution License 4.0 International License

\begin{abstract}
Professional Learning Community (PLC) is a form of self-development for educators which has been known internationally and currently through the phase of implementation in Malaysia. Purpose of this study was focused on PLC implementation that had been applied widely in Higher Education Institution (HEI) which; 1) to identify the relationship between educators' comprehension, readiness and strategies for language learning, and 2) to form a predictive model of relationship between educator's knowledge, preparation and strategy toward improving student's language learning. Three dimensions of PLC which comprehension, readiness and strategies in PLC were analyzed by using SPSS and AMOS. Three hundred sixty students and five lecturers involved as respondents. Correlation analysis and structured equation modeling were used to answer the research objectives. Qualitative data as the predictive model achieved a good fit value of RMSEA $=.055$, GFI $=.980, \quad$ CFI $=.981$, TLI $=.983$ and Chisq $/ \mathrm{df}=2.164$. Interview data of 5 educators showed that decency was the main key theme in improving student language learning achievement. The implementation of PLC that related to language as well decency learning had given a new approach in teaching, particularly for educators and students in a language course. The predictive model can be used as primary source guidelines in elevating the Malay language at a higher level, especially for next researches. Secondary source supported the findings. Results showed that there were significant values derived from the relationship between comprehension and language learning $(\mathrm{r}=.401, \mathrm{p}=.000)$, the relationship between readiness and language learning $(\mathrm{r}=.541, \mathrm{p}=.000)$, and the relationship between strategy and language learning $(\mathrm{r}=.891, \mathrm{p}=.000)$.
\end{abstract}

Keywords Professional Learning Community (PLC), Comprehension in PLC, Readiness in PLC, Strategy in PLC, Predictive Model

\section{Introduction}

Formal or informal language generally divides into three primary levels, which are delicate or polite language, rough language and abusive language. Respectful communication means the most beautiful expression is used to replace certain words that thought as rude or can hurt other people's heart and feeling (Asmah, 2008). The use of polite language is an effort to deliver communication with suitable ways so that the individual who involves in communication events does not receive unwanted impacts. The use of beautiful or polite language often relates to the concept of speech or language act among individuals who speak the language.

Language act means daily speech that gives specific meaning according to particular contexts. It is a form of language that produces to create actions, and different from sentences as well cannot be related to other grammar levels. Language act consists of various types such as greeting, requesting, apologizing, complimenting and rejecting. For example, is the following sentence, "He told me to join this program. hmm it is quite interesting. But, he already joined other activity, madam". This sentence can give meaning that the speaker wants to reject his friend's suggestion to join the program organized by the university, whereas his friend does not enter the program. The speaker does not use correct sentences maybe not to offend his friend's honor or feeling. The structure of speech usually depends on gender, social factors and context of learning culture in Malaysia. Educator's influence as a role model to the students also plays essential roles in creating language act. Language act is very related to the concept of linguistic politeness. This relatedness is vital in the relationship between educator and student. Language act always relates to etiquette, moral and delivery that can help to teach the quality of educator (Wilson, 2016). 
Therefore, educator plays important roles to help students to drive themselves towards elevating self with positive attributes through the implementation of PLC. The term of PLC has been common to debate in society. It has been used to illustrate a practice that implemented continuously (Dufour,2008). For example, in the context of teaching force at $\mathrm{HEI}$, an educator can continue the exercises in lecture rooms to the community, or bring a community to HEI to support learning and teaching session by involving students, educators and administration through collaboration in education (Dima Mazlin \&, Abdul Rasid, 2016). This is similar to the interpretation by Wilson, (2016) who names it as a community that continue to implement research activities and make improvement. To ensure it can be achieved, an educator must involve continuously in finding and sharing learning as well as practising the knowledge so that students can gain benefits (Mohd. Faiz, Muhammad Rozaimi \& Jamal, 2016).

Thus, this study was conducted to identify how far the relationship between practices of PLC that had been fully implemented through five strategies as outlined by Dufour, (2004) in helping language decency aspect among students who were taking a language course at HEI in Malaysia. Student perception towards their educator was identified according to research objectives as follows:

1). to determine the relationship between educators' comprehension, readiness and strategies in PLC implementation with increasing language learning of a student, and;

2). to form a predictive model of the relationship between educator's knowledge, preparation and strategy in PLC implementation with increasing language learning of selected HEI student in Malaysia.

Hence to answer the objectives there are three hypotheses were tested, as follows;

H1: There is a significant relationship between dimensions of comprehension with achievement in enhancing language learning among the students in a higher education institution of Malaysia.

$\mathrm{H} 2$ : There is a significant relationship between dimension of readiness to implement PLC with achievement in enhancing language learning among the students in a higher education institution of Malaysia.

H3: There is a significant relationship between dimension of strategy in PLC with achievement in enhancing language learning among the students in a higher education institution of Malaysia.

\section{Background of the Study}

Language learning has been studied a lot by linguists. Meanwhile, there is a lack of research about language learning in the context of Malay language community in Malaysia that connected with PLC. This is because learning decency learning particularly in the context of Malay language has not been studied in detail except while discussing the aspects of language activities such as indirectness (Mansor, Ahmad \& Yaakub, 2010). It is similar to the study that combines both PLC and decency language variables in Malaysia. However, there is empirical proof to relate the relationship between these two variables by studies that have been done in Malaysia and other countries.

For example, PLC in Higher Education Systems' have been proved that the implemented was created the conditions where educators support one another's practice in PLCs, educator's feel more confident and develop a strong sense of self-efficacy; they believe in their ability to influence student learning and make a difference in student outcomes and achievement. This appears to strengthen teachers' commitment to working collaboratively with their peers and improving their instruction to meet students needs (Margalef \& Pareja Roblin, 2016).

\subsection{Language and Decency Learning among Students}

Generally, language learning is divided into few categories. Decency aspect is a communication skill that creates verbal interaction or relation through a medium or vice versa with other people. According to Chong, Muhammad Faisal \& Zuraidah (2015), the communication process is the foremost necessary and cannot be avoided by someone in doing daily activities. This is because the process occurs by itself when interaction exists between two individuals. At the same time, decency becomes essence in the smooth communication process, and speech goals can be delivered precisely to the receiver.

An educator is a medium that develop student's personality. Education institution is a social institution that emphasised the importance of effective communication in the classroom to create universal social development (Badrul Hisham \& Mohd. Nasaruddin, 2016). The decency of spoken language creates active learning. It is an interactive process that gives space for students to interact, help each other, carry out the responsibility, build confidence, and so on (Jyh, 2013). Even, students are encouraged to give opinions and ideas effectively if teaching and learning held in an attractive and fun environment. Besides, spoken decency language gives implication from the social skills aspect by helping students to react with the environment as well self-control in facing challenges to enhance self-excellence (Mansor,.et.al, 2010).

Along with the past findings, Ismail, Ghani \& Abdullah, (2014) emphasise that educator who has excellent communication skills in building attractive and fun teaching environment can influence student's decency in expressing the language well. A study by Norhiza, Faridah \& Farah, (2014) proves that the ability to communicate efficiently can help the educator to apply positive attributes such as language decency Mansor, et. al, (2010). Therefore, an educator must have interest, experience and fundamental professional skills to produce students with virtue includes the aspects of social, physical and emotion (Intel, 2014). Mansor,.et.al (2010) have stated that spoken decency language is a process that gives meaning and able 
to influence someone to believe and do something as asked.

This is because polite words either verbal or non-verbal, will involve knowledge transfer, understanding or feelings that are shared through the delivered message (Maros, 2011). In the context of teaching, educator functions as an individual who provides knowledge and must have various types of skills include speech, classroom control, teaching technique and use effectively as well as organize communication. Professional responsibility must be implemented wisely and systematically. This is because educator not only deals with students but also with other people such as community and administration. Educator not only functions to deliver knowledge but must build interaction through various paths which lead to the smoothness of teaching and learning process and produce students with better decency language.

\subsection{Professional Learning Community (PLC) at HEI}

Professional Learning Community (PLC) defines as a practice that must be implemented continuously in the long term. According to Ruland [25], PLC is a culture factor which contributes to the success of the organization. In defining PLC, Dufour, (2008) argue that educator must give high commitment in doing works through collaboration especially in inquiry collective activity and action research to produce better findings. While Smith, (2013) states that PLC is a practice at the workplace which involving active and efficient teaching activity. This is due to the contributory factors of success such as efforts of the administration in supporting educator's learning and high commitment levels of co-workers. In further, PLC is a practice that emphasized on collaboration aspect among the community in the organization. There are five dimensions, as suggested by DuFour, (2008) in explaining the implementation of PLC. However, this study only focuses on three big dimensions which are;

\section{(a) Comprehension Dimension}

This dimension divided into three aspects which are knowledge sharing, vision and mission as well as values. Vision can be formed by asking stakeholders in teaching about what is their expectation towards institution (Hord \& Hord, 2003). Meanwhile, the effectiveness of the vision statement is specifically on the future of the organization, and it is enabled to motivate the institution's community to achieve the vision (Dufour, 2004 \& Wilson, 2016). Therefore, building a vision is one of the success factors for the institution in the long term (Rosenholtz, 1985). Ezwafahmey, (2018) states that PLC practices can be achieved if the institution has a clear vision, mission and values which can be shared with stakeholders. In other words, educator and the higher management need to share the vision, mission and values of the institution that supported together with students.

Therefore, this strategy also helps the community in HEI organization to develop a clear picture of the collaborative work that educators can do in PLCs, when they were really shared vision and mission to achieve. It could be demonstrated by interactive sessions include modeling the collaborative routines, professional behaviors, and collegial practices that are crucial to holding productive PLC meetings (Bangeni \& Kapp, 2017).

\section{(b) Strategy Dimension}

An educator who implements the practices of PLC must continuously identify the best teaching strategy to enhance student achievement. The wish will come true if educators perform their works in an environment that encourages collaboration (Hargreaves \& Fink, 2018). In HEI organization, educators always need to create reflection dialogue, do self-assessment and solve student's learning problems together (Roslizam, Jamilah \& Yusof, 2018). This will lead to the improvement of teaching pedagogy in the educator's lecture room (Wilson, 2018). Therefore, the head of the institution must support educators by giving them a period to implement collaboration (Badrul Hisham \& Mohd. Nasaruddin, 2016).

From the collective aspect, the community of institution that practices PLC usually gives focus on the action after setting a mission to achieve the vision (Dufour, 2004). This action is in the form of action research to identify the best strategy in teaching, Dehdary, (2017) that carried out by collective and continuously (Ezwafahmey, 2018). Accurately, Dufour, (2008) state that the focuses of inquiry collective in PLC are as follows; (i) identify the best practice in teaching and learning, (ii) evaluate the development of nowadays practice, and (iii) assess the trend of student's academic achievement. Inquiry collective will enable to enhance new skills of the institution community and change the behavior as well as belief (Chauraya \& Brodie, 2015).

Therefore, the administration and management of the institution must provide educators with information and knowledge basis about their research so that they can make the right decision on student's achievement. This is explained by Siti Nafsiah, Zuraidah, Abdul Jalil \& Salwati, (2018) that higher management needs to guide educators to analyze and interpret data about student's achievement, provide time and schedule for educators to discuss about student's performance, and provide time for educators to be guided about action research to cultivate love in research culture. This kind of supports will enable educators to implement inquiry collective continuously because they are transparent with guidance and goals set by the higher management.

So that, the educators will get the benefit from assistance from those who can bring specific expertise to PLCs, such as how to analyze data, unpack standards, identify the most effective instructional strategies to address a standard, identify effective assessment strategies, use student work as a reflective tool in PLCs, and adjust instruction to meet student (Baygin, Yetis, Karakose, \& Akin, 2016).

\section{(c) Readiness Dimension}

This dimension is divided into two aspects which are structure and leadership. Effective leadership is a leader who gives some powers to subordinates employers (Dufour 
\& Eaker, 2008). For example, the head department involves educators in making decision collaboratively through these following efforts; (i) encourages educators to take risks and try something new, (ii) provide reinforcement and positive motivation, (iii) give opportunity for educators to enhance self-competency, (iv) provide time for educators to supervise and do reflection (Dufour, 2008 \& Smith, 2018).

Somehow the leaders for example the dean or head of department in HEI organisation can assist educators in connecting PLC meetings and changes in instructional practice by regularly attending PLC meetings and conducting learning walks, a process in which a small team participates in classroom walkthroughs to observe how decisions made in PLC meetings are implemented in the classroom. This element also would be a good starting point to polish the readiness to implement the PLC in HEI.

Therefore, educators must increase competency to face the increase of responsibilities (Dufour, 2008). Ratts, Pate, Archibald, Andrew, Ballards \& Lowney, 2015) explained that competency levels of educators are essential because the current position of educators as a leader is forcing them to increase commitment and accountability to achieve the goals of the institution.

\section{Methodology}

\subsection{Research Design}

This study was conducted to identify the relationship between PLC implementation with increasing student's language learning. Therefore, quantitative method of survey was used by using a questionnaire. A qualitative approach as a secondary source was used to collect summative data as support by interviewing five educators. This research design was flexible, which could be modified according to the situation's needs.

\subsection{Research Sample}

This study involved 360 students at five public HEI. The data was collected by distributing questionnaires forms to students. All questions and answers were in the Malay language. At the same time, the researcher went to the field study to observe while the program was being held with students as respondents to get empirical proof about how far language learning achievement particularly decency language had been mastered by them. Five educators were being interviewed to get secondary data as support.

\subsection{Data Collection and Instrument}

All participants completed the research surveys assessing their perception of how well the PLC's dimension has been implemented in the university setting in a language course. While the researcher has interviewed five academic staff who from selected universities to provide any information about the implementation of PLC in their organization. The Professional Learning Community Assessment (PLCA) questionnaire was employed in this study. The instrument was adapted from Olivier \& Hipp, (2010). It consisted of 56 items was combining five Likert's scales in measuring three dimensions of PLC, i.e. shared values, vision \& mission; collective learning and application and leadership \& supportive sharing.

\subsection{Reliability and Validity of the Instrument}

Reliability is defined as how consistent a measuring device is. Besides, a measurement is deemed reliable or consistent when similar results can be replicated in similar circumstances. To establish the reliability of the analysis of this study, the Cronbach Alpha value of $\leq 0.60$ is considered to be not reliable, while more than $\geq 0.70$ indicates that it is highly acceptable. The reliability analyses for this research were presented in Table 1.

Table 1. Reliability Analysis of Construct

\begin{tabular}{|c|c|c|}
\hline Constructs & $\begin{array}{c}\text { Number of } \\
\text { Items }\end{array}$ & Alpha Cronbach \\
\hline Comprehension & 15 & 0.809 \\
\hline Readiness & 15 & 0.861 \\
\hline Strategy & 26 & 0.781 \\
\hline Language Learning & \multicolumn{2}{|c|}{ Self-reported by students } \\
\hline
\end{tabular}

All the dimensions were achieved the high acceptable value when alpha Cronbach value $>.60$. The dimension of comprehension $=0.809$, dimension of readiness $=0.861$, dimension of strategy $=0.781$ and dimension of language learning was self-reported by students based on their marks given in their exam. Therefore, this instrument was achieved the reliability and validity to measure all the variables in this research.

\section{Analysis and Findings}

The data were analyzed using correlation and regression analysis by the method of structural equation modeling. The correlational study was applied to test the assumption of whether there is a statistical relationship between the variables.

\subsection{Correlation Analysis}

Findings of correlation analysis showed that there was a significant relationship between all measured variables. Results were as in Table 2 below;

Table 2. Correlation Analysis of Comprehension, Readiness, Strategy and Language Learning

\begin{tabular}{|c|c|c|c|c|}
\hline & $\mathrm{C}$ & $\mathrm{R}$ & $\mathrm{S}$ & $\mathrm{LL}$ \\
\hline Comprehension & 1 & & & \\
\hline Readiness & $.676^{* * *}$ & 1 & & \\
\hline Strategy & $.709 * * *$ & $.757^{* * *}$ & 1 & \\
\hline $\begin{array}{c}\text { Language } \\
\text { Learning }\end{array}$ & $.524 * * *$ & $.585^{* * *}$ & $.704 * * *$ & 1 \\
\hline
\end{tabular}

Note: C: Comprehension Dimension; R: Readiness Dimension; S: Strategy Dimension; LL: Language Learning; $\mathrm{N}=360$; $* * *$ Significant at, $\mathrm{p}=.000$ 
Based on Table 2, correlation analysis showed that there was a significant relationship between comprehension and student's language learning $(r=.524, p=.000)$. The direction of relationship for both variables was positive, which means the knowledge of educator on PLC implementation had direct contact with the achievement of student's language learning. This gave the perception that educators at HEI understood the vision, mission and goals of PLC implementation, which bring implication towards the increase of success in student's language learning. Next, readiness and outcomes of student's language learning $(r=.585, p=.000)$ showed significant and positive value. This means the higher readiness of educator in implementing PLC, the better outcomes of student's language learning. A positive, meaningful relationship also was shown between the strategy of implementing PLC with the results of the student's language learning $(r=.704$, $p=.000)$. These results were supported hypotheses testing for $\mathrm{H} 1, \mathrm{H} 2$ andH3.

\subsection{Structural Equation Modeling}

Structural Equation Modeling (SEM) analysis was done to produce a predictive model for the relationship of educator's comprehension, readiness and strategy in PLC implementation with increasing of student's language learning. This analysis showed good compatibility value to verify the predictive model, which had been developed Results of SEM analysis showed the compatibility value as follows; $\mathrm{RMSEA}=.055, \mathrm{GFI}=.980, \mathrm{CFI}=.981$, $\mathrm{TLI}=.983$ and Chisq/df=2.164 (Figure 1).

Based on the results of SEM analysis in Figure 1, good compatibility value was achieved, and this showed that factors of educator's comprehension, readiness as well strategy to implement PLC had contributed towards increasing of language learning among students. About 59\% of variance value had been contributed by factors of educator's comprehension, readiness and strategy. From the three dimensions that had been studied, educator's preparation which was structural and leadership showed the highest contribution with $\beta$ value $=.89$ compared to comprehension and strategy dimensions.

Meanwhile, educator's comprehension which related to knowledge sharing, vision and mission as well attributes showed the lowest contribution with $\beta$ value $=.40$. Strategy dimension which was collaborative and collective aspects only gave $\beta$ value $=.54$, positioned in a range of $50 \%$ contribution value towards language learning. Good compatibility value that had been achieved will build a predictive model for the relationship of comprehension, readiness and strategy with language learning.

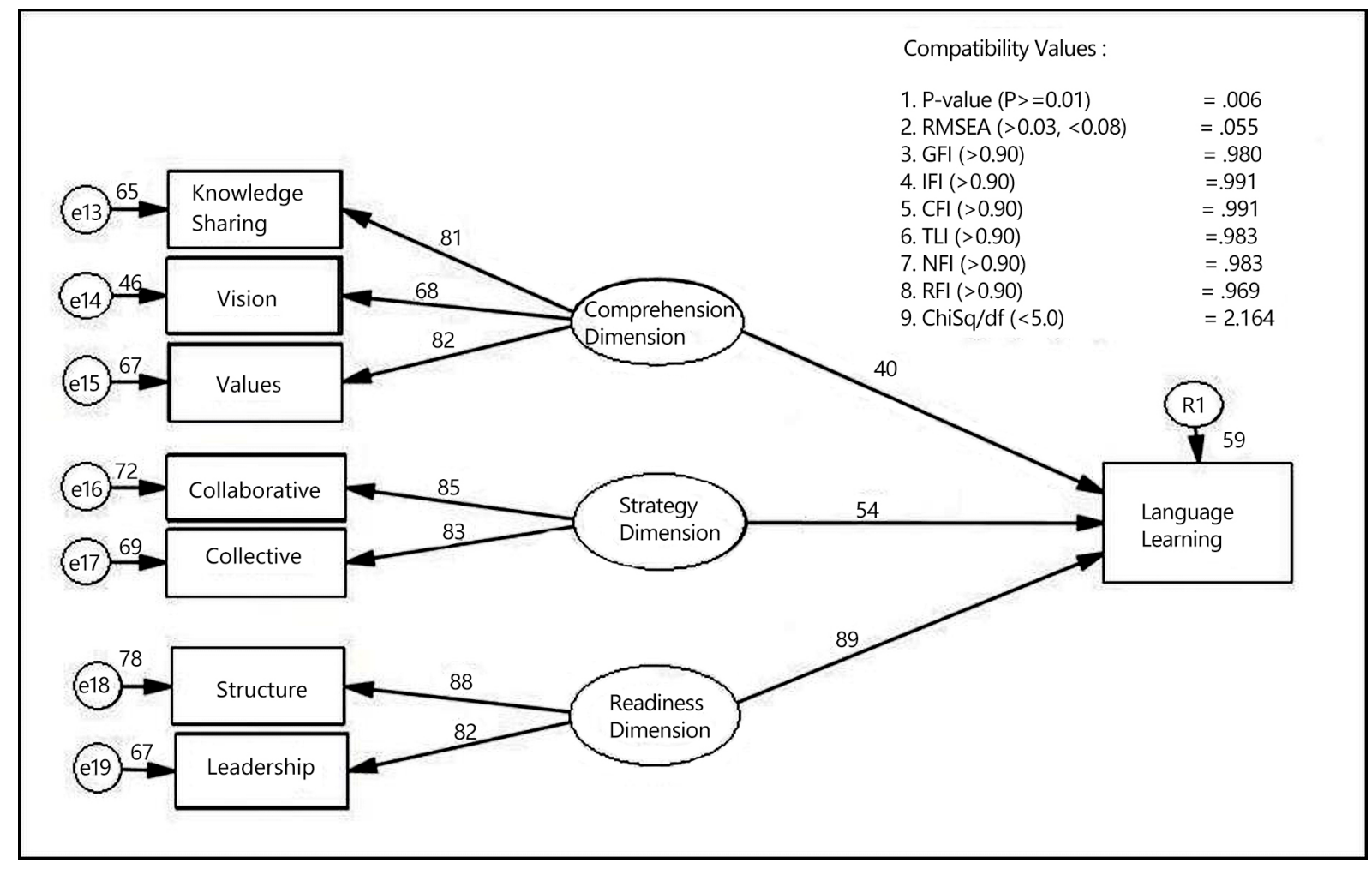

Figure 1. Predictive Model of Relationship between Comprehension, Readiness, and Strategy with Student's Language Learning 


\section{Discussion}

The language learning process is a must for students to ensure continuity of communication occurred. This study had found three dimensions of PLC implementation that played important roles to enhance student's language learning achievement at chosen HEI. Reference [22] agreed that if an institution wished to create a learning community among educator and students, the higher management should play their roles effectively and efficiently. In other words, there was a relationship between dimensions that had been studied with aspects of commitment, effort to develop community by collaboration and sharing practice during PLC implementation.

\subsection{PLC Implementation and Its Relationship with Language Learning from the Student's Perspective}

This study explored the relationship between educator's comprehensions, readiness as well strategy of PLC and proved that there was mutual interaction between all variables in enhancing student's achievement in language learning. Comprehension dimension was being studied on how far educator understood the vision, mission and values that shared by an institution with students. Findings showed that educator who had clear vision should view any problems in the organization's scope and the solutions must be guided by a vision that had been fixed at the institution level.

Therefore, educator and higher management should draft the vision together to make it as implementation guideline in any actions that would be taken on issues related to student's learning. The secondary source also supported the statement that comprehension of vision and values which shared would contribute to better achievement in student's education. Shared information and knowledge could simplify the comprehension process among students on what would they achieve in their learning process as quoted in the second respondent's answer;

"yes, we explained about vision and mission at the beginning of class, the outcome was the students were clear with the goals that must be achieved, so at the end of semester usually there were changes. Students were more confident to speak with friends ..." (R2, 35-37)

Findings also shows that collective and collaborative culture in strategy dimension of PLC implementation connected co-operation between educator, higher management and students that helped better language learning occurred (Smith, 2018). The community in the institution solved the problems together and improved the chances of collaboration learning. This caused the relationship within the community which educator, higher management and students became closer and increased the level of commitment to improve language learning. This was supported by secondary data from the respondent as follows;
“ ...in ensuring the success of one program such as short drama at the end of the semester, we divided students into groups. Many problems aroused at the beginning of the program. But, after we asked students to collaborate with different groups, they exchanged ideas and could do the show with excellence." (Rl, 75-80)

Meanwhile, focus commitment which mentioned in institution structure aspect and leadership were representing readiness dimension to illustrate close relationship within the community in the institution. In structure form, the higher management should give space and chance to the inside community to enhance self-achievement. For a close relationship within society, the higher management should self-communicate with educator and students to create excellent communication between them and enable the institution to achieve the vision that had been fixed.

These findings are similar to the study by Dehdary, (2017) who found that all parties were mutually respecting, believing and concerning to increase achievement. From the structure and leadership aspect, Dufour \& Eaker, (2008) stated that higher management caused the barrier of effectiveness towards improvement in organization. The approaches used by the educator from top to bottom produced less commitment among the community of organization (Inatanam \& Wongwanich, 2013). The success would become meaningful if HEI made efforts with stakeholders through collaborating and co-operating (Tan, Wong, Zulkifli, Teh, Latifah \& Saripah Rabeah, (2017).

This study also had found a particular theme that was language decency which part of language learning element. It played vital roles for the effectiveness of PLC implementation as mentioned by the third and fourth respondent;

"my students showed changes; they spoke with more polite language..courtesy, figurative when lecturer showed he was listening, always communicated with them, for example when we met while walking, they greeted me..with respective titles compared to before, they did not realise my existence in their group "... [R3, 120-160].

A statement from the fifth respondent supported this finding;

"my students interacted well in class, they called their friends politely, even they began to voice their own opinions when certain activities were held, such as theatre show that we made last semester, it was quite fascinating when majority of my students were able to make plans, worked well in groups, did not fight like previously. All of these happened after we hold meetings, their voices were heard..all parties played their roles, head of the department joined to hear, educators also there and students definitely as an activator. The outcomes, yes..they able to do the show successfully and their soft skills became better, I mean 
ways if they spoke, they could interrupt well during conversation ..." [R5, 201-220].

A study by Chong, Muhammad Faisal \& Zuraidah, (2015) stated that Malay decency concern about harmony relationship and the concept of honour which negative language could dishonour the listener. This means that a good relationship between all parties by implementing PLC could help students to create better decency language. Although there was a different perception among students about the three dimensions that were tested in PLC implementation, an agreement was reached when these factors had contributed to the learning outcomes of students in HEI.

According to the findings, readiness dimension showed more contribution percentages compared to comprehension and strategy. This could be explained that although students realized the educator understood the vision and organization values, shared knowledge, cooperated in implementing PLC, but the readiness of educator from structure aspect such as practicing culture of mutually trust each other and creating continuous efforts were more important to help learning process. This goal could be achieved through the implementation of constant activities as well as interferes from educator and administration (Jones, Stall \& Yardbourgh ,2013).

It could be concluded that correctly, this study had found three main dimensions in PLC implementation which comprehension, readiness and strategy that contributed to student's language learning. In other words, the effectiveness of PLC implementation needs changes in process systematically and done in the long term by involving all parties. Researcher Roslizam, Jamilah \& Yusof, (2018) also mentioned that a successful organization was an organization that able to build future based on its mound, realized that changes process was complicated and needed long term, had vision and mission and cared towards feedbacks.

\section{Conclusion}

The predictive model built could be used as a basic guideline for the government to uplift the Malay language as in teaching plan that had been drafted to ensure country teaching system parallel to global modernization (Ezwafahmey, 2018). Government effort as mentioned in Teaching Development Plan 2012-2025 was to provide all students (a) expert in the Malay language, (b) produce Malaysian that appreciate positive attributes, (c) increase quality of educator, and (d) potential leader practice good leadership. These efforts were included in PLC implementation which should be done continuously. This model clearly showed that contributory factors from comprehension, readiness and strategy aspects in PLC implementation had contributed to increasing student's language learning.

As a conclusion, the implementation of effective PLCs depends on engaging between educators and students at HEI in ongoing conversations about teaching and learning that are directly related to their daily work. For that to happen, the dean, head of department or leaders in HEI's organization must provide support and feedback and cultivate an atmosphere of sharing and trust, the conditions in which PLCs can thrive. When educators foster these professional learning environments, educators can act on the guidance that fellow educators provide to solve significant issues faced by educators and as a profession.

\section{Acknowledgements}

This study was supported by research funds from Universiti Putra Malaysia [Project Number: GP-IPM/2017/9564600]. We would also like to acknowledge the contributions of the research assistants who have aided the research team in gathering data and putting this report together.

\section{REFERENCES}

[1] Badrul Hisham, A., \& Mohd. Nasaruddin, B. (2015). Amalan Pengajaran dan Pembelajaran Abad ke-21 dalam Kalangan Pensyarah Institut Pendidikan Guru kampus Ipoh. Jurnal Penyelidikan Dedikasi, Vol. 10, No.5, 1-25, 2016.

[2] Badrul Hisham, A., \& Mohd. Nasaruddin, B. (2015). Penilaian Kendiri Amalan Pengajaran Dan Pembelajaran Abad Ke -21. In Seminar Penyelidikan Zon Sabah, At Keningau, Sabah, pp 1-36.

[3] Bangeni, B., \& Kapp, R. (2017). Negotiating learning and identity in higher education: Access, persistence and retention. Bloomsbury Publishing.

[4] Baygin, M., Yetis, H., Karakose, M., \& Akin, E. (2016). An effect analysis of industry 4.0 to higher education. In 2016 15 th international conference on information technology based higher education and training (ITHET) (pp. 1-4). IEEE.

[5] Chauraya, M., \& Brodie, K. (2017). Learning in professional learning communities: Shifts in mathematics teachers' practices. African Journal of Research in Mathematics, Science and Technology Education, Vol. 21, No.3, 223233.

[6] Chong, C.K,.Muhammad Faisal, A.G \& Zuraidah, A. (2015) Amalan Komuniti Pembelajaran Profesional (KPP) di Sekolah Berprestasi Tinggi (SBT) Malaysia: Sebuah Sekolah Jenis Kebangsaan Cina (SJKC) di Sarawak. Jurnal Kepimpinan Pendidikan, Vol., No. 4, 32-46.

[7] Dehdary, N. (2017). A Look into a PLC. Journal of Language Teaching and Research, Vol. 8, No.4, 645-658.

[8] Dima Mazlina, A.B., \& Abdul Rasid. J. (2016). Pelaksanaan Komuniti Pembelajaran Profesional Untuk Peningkatan Kemahiran Guru Bahasa Melayu Mengajar Penulisan Karangan. JuKu: Jurnal Kurikulum \& Pengajaran Asia Pasifik, Vol.4, No.3, 1-10.

[9] Dufour, R. (2004). What Is a " PLC"? Big Idea \# 1 : Ensuring That Students Learn. Educational Leadership, Vol.61, No.8, 1-6. 
[10] DuFour, R., \& Eaker, R. (2008). New Insights for Improving Schools. In Revisiting of Professional Learning Communities at Work. Bloomington: National Education Services.

[11] Ezwafahmey, A.K. (2018). Tahap Kesediaan Guru Cemerlang Bahasa Melayu terhadap Pelaksanaan Komuniti Pembelajaran Profesional di Sekolah Menengah di Negeri Melaka. Malay Language Education Journal, Vol. 8, No.5, 63-73.

[12] Hargreaves, A., \& Fink, D. (2008). Distributed Leadership : Democracy or Delivery? Journal of Education Administration, Vol. 46, No.2, 229-240.

[13] Hord, S.M \& Hord, S.M. (2003). Professional Learning Communities of Continuous Inquiry and Improvement and Improvement (Second Edi). Austin, Texas: Southwest Educational Development Laboratory.

[14] [14] Inatanam, N., \& Wongwanic, S. (2013). An Application of the PLC Approach to Developing the Learning Process and Enhancing Academic Achievement in the Mathematics and Science Teaching of the Primary School Student. Procedia - Social and Behavioral Sciences, Vol. 131, No.4, 476-483.

[15] Intel. (2014) How the PLC Impact Student Success.

[16] Ismail, A., Ghani, A., \& Abdullah, K.(2014). PLC practices in high and low performing schools in Malaysia. International Jurnal of Current Research and Academic Review, Vol.2, No.9, 159-164.

[17] Jones, L., Stall, G., \& Yarbrough,.D. (2013). The Importance of Professional Learning Communities for School Improvement. Creative Education, Vol.4, No.5, 357-361.

[18] Jyh, W.S. (2013). Ke Arah Penilaian, Perkembangan dan Pemupukan Bahasa Melayu Supernasional. Kajian Malaysia, Vol. 31, No.2, 87-104.

[19] Mansor, N., Ahmad.,F. \& Yaakub, Y. (2010) Kesantunan Bahasa Dalam Kalangan Pelajar IPT: Satu Kajian Perbandingan Etnik, Vol. 1, No.1, 337-352.

[20] Margalef, L., \& Pareja Roblin, N. (2016). Unpacking the roles of the facilitator in higher education professional learning communities. Educational Research and Evaluation, 22(3-4), 155-172.

[21] Maros,M. (2011). Strategi Kesantunan Melayu dalam Membuat Teguran. E-UTAMA, Vol. 3, No.1,7-20.

[22] Mohd Faiz, Y., Muhamad Rozaimi, R., \& Jamal@Nordin, Y.M. (2016). Konsep Kolaborasi Dalam Komuniti Pembelajaran Professional : Satu Tinjauan Dari Perspektif Islam. Malaysian Journal of Society and Space, Vol. 12, No.10, 1-9.

[23] Nor Asmah,.O. (2008). Ragam Bahasa. Ensiklopedia Bahasa Melayu. Kuala Lumpur: Dewan Bahasa dan Pustaka.

[24] Norhiza, M.S., Faridah, N.S., \& Farah, M. (2014). Pemupukan Kemahiran Insaniah Melalui Kursus Bina Insan Guru Dalam Kalangan Siswa Guru Institut Pendidikan Guru. Jurnal Personalia Pelajar, Vol. 17, No.1, 9-17

[25] Olivier,. D.F \& Hipp, K.K. (2010). Assessing and analyzing schools as professional learning communities. In K. K. Hipp \& J. B. Huffman (Eds.), Demystifying professional learning communities: School leadership at its best. Lanham, MD: Rowman \& Littlefield, 2010.

[26] Ratts, R.F, Pate, J.L., Archibald, J.G., Andrews, S.P.,
Ballard, C.C., \& Lowney. K.S. (2015). The Influence of Professional Learning Communities on Student Achievement in Elementary Schools. Journal of Education \& Social Policy, Vol. 2, No.4, 51-59.

[27] Rosenhlotz, S.J. (1985). Active Schools: Interpreting the Evidence. American Journal of Education, Vol. 93, No.3, $352-388$.

[28] Roslizam, H., Jamilah, A., \& Yusof, B. (2018). PLC in Malaysia. International Journal of Engineering \& Technology, Vol.7, No.3, 330-433.

[29] Ruland. R. (2015). Understanding The Experience of Teachers In A PLC: A Case Study of An Interdisciplinary Ninth Grade Team. Northeastern University.

[30] Shamsudin, O. (2018). Kesantunan Bahasa dalam Aspek Penguasaan Pengajaran, dalam Dewan Budaya, Oktober 2018, Kuala Lumpur: Dewan Bahasa dan Pustaka.

[31] Siti Nafsiah, I., Zuraidah, A., Abdul Jalil, O., \& Salwati, S. (2018). Amalan Komuniti Pemebelajaran Profesional Dalam Kalangan Guru Bahasa Melayu di Selangor. Jurnal Kepimpinan Pendidikan, Vol. 5, No.4, 19.

[32] Smith, K.L. (2013). The relationship between professional learning communities and student achievement. ProQuest Dissertations and Theses, 103.

[33] Tan, A.L., Wong, K.W, Ooi, S.Y., Zulkifli, Y., Teh, H.L, Latifah, J., \& Saripah Rabeah, S.A. (2017). Amalan Berkolaborasi untuk Pembelajaran di Institut Pendidikan Guru. Jurnal Penyelidikan Dedikasi, Vol. 12, No.1, 120-132.

[34] Wilson,. A. (2016). From Professional Practice to Practical Leader: Teacher Leadership in Professional Learning Communities. International Journal of Teacher Leadership, Vol. 7, No.2, 45-62, 2016. 